\title{
SILICON MOLECULAR BEAM EPITAXY : A COMPREHENSIVE BIBLIOGRAPHY 1962-82
}

\author{
J.C. Bean and S.R. McAfee \\ BeIZ Labs, Murray Hizl, New Jersey 07974, U.S.A.
}

\begin{abstract}
Résumé.- Nous avons compilê une bibliographie de plus de 200 références $\dot{s}$ 'ẻtendant sur les 20 premières années de 1 'épitaxie par jets moléculaïres du silicium. EJM-Si est đéfinie largement afin d'inclure une série de publications sur les méthodes de dépôt de silicium sous-ultravide. Cette définition permet d'inclure les premiers travaux dans le domaine et des approches alternatives de croissances épitaxiales telles que le dépôt en phase vapeur partiellement ionisée, l'épitaxie par faisceau d'ions et l'épitaxie en phase solide. Les références sont données avec les titres dans 10 catégories de sujets. Dans ces catégories, les articles sont inscrits alphabétiquement par premier auteur en respectant 1a chronologie. Les catégories se recoupent et les traductions en anglais citées, si disponibles. Les citations sont limitẻes aux travaux en cours d'impression ou acceptés pour publication. Après la bibliographie. des numéros de rêférences par auteurs sont donnés par ordre alphabêtique. Les catêgories sont les suivantes :
\end{abstract}

I. REVUES (REF. 1-8)

II. PREMIERS TRAVAUX (REF, 9-43)

(articles ou projets achevés en 1972)

III. APPAREILIAGE (REF. 44-48)

IV. PREPARATION DES SUBSTRATS (REF. 49-6I)

V. HOMOEPITAXIE

A. NON DOPE OU DOPE PENDANT L'EPITAXIE (REF. 62-106)

B. DOPE PAR IMPLANTATION (REF. 107-119)

VI. DEPOT DE SILICIUM IONISE (REF. 120-138)

(incluant le dépôt en phase vapeur partiellement ionisée et 1 'épitaxie par faisceau d'ions)

VII. HETEROEPITAXIE

A. SUBSTRAT ISOLANT (REF. 139-153)

B. CROISSANCE ISOLANT/SILICIUM (REF. 154-157)

C. CROISSANCE METAL/SILICIUM (REF. 158-178)

D. CROISSANCE SEMICONDUCTEUR/SILICIUM (REF: 179-193)

VIII. EPITAXIE LOCALISEE (REF. 194)

IX. STRUCTURES DE DISPOSITIFS (REF. 195-204)

X. DEPOTS NON EPITAXIES (REF. 205-223)

(incluant l'êpitaxie en phase solide et recuit laser sous pression de silicium, et le dêpôt de silicium polycristallin) 


\section{Abstract. -}

We have compiled a Bibliography of over two hundred references spanning the first twenty years of Silicon Molecular Beam Epitaxy. Si-MBE is defined broadly to include a range of publications involving high vacuum deposition of silicon. This definition permits the inclusion of early work in the field and alternative approaches to epitaxial growth such as partially ionized vapor deposition, ion beam epitaxy and solid phase epitaxy. References are listed with titles in ten subject categories. Within these categories papers are listed alphabetically by first author in chronological succession. Categories are cross referenced and English translations are cited, if available. Citations are limited to works in print or accepted for publication. Following the bibliography reference numbers are listed by authors alphabetically. Categories in the bibliography are listed below:

\section{REVIEWS (REF. 1-8)}

II. EARLY RESEARCH (REF. 9-43)

(papers or projects completed by 1972)

III. APPARATUS (REF. 44-48)

IV. SUBSTRATE PREPARATION (REF. 49-61)

V. HOMOEPITAXY

A. UNDOPED OR WITH EVAPORATED DOPANTS (REF. 62-106)

B. IMPLANTED DOPANTS (REF. 107-119)

VI. IONIZED SILICON DEPOSITION (REF. 120-138)

(including partially ionzed vapor deposition and ion beam epitaxy)

VII. HETEROEPITAXY

A. INSULATING SUBSTRATES (REF, 139-153)

B. INSULATOR/SILICON GROWTH (REF. 154-157)

C. METAL/SILICON GROWTH (REF. 158-178)

D. SEMICONDUCTOR/SILICON GROWTH (REF. 179-193)

VIII. PATTERNED EPITAXY (REF. 194)

IX. DEVICE STRUCTURES (REF. 195-204)

X. NON-EPITAXIAL DEPOSITION (REF. 205-223)

(including solid phase epitaxy and laser annealing using evaporated silicon, and polycrystalling silicon deposition) 


\section{BIBLIOGRAPHY}

\section{REVIEWS}

1. Allen, F. G., Iyer, S. S., and Metzger, R. A., "Molecular Beam Epitaxial Growth of Silicon Devices," Proc. of the Los Angelas Technical Symposium and Exibition of the Society of Photooptical Instrumentation Engineers (1982).

2. Bean, J. C., "Growth of Doped Silicon Layers by Molecular Beam Epitaxy," Chap 4 in Impurity Doping Processes in Silicon, Materials Processing: Theory and Practice, F. F. Y. Wang Ed, North Holland (1981).

3. Bean, J. C., "Silicon Molecular Beam Epitaxy as a VLSI Processing Technique," IEDM Technical Digest, p. 6 (1981).

4. Joyce, B. A., "The Growth and Structure of Semiconducting Thin Films," Rep. Prog. Phys. 37,363 (1974).

5. Ota, Y., "Silicon Molecular Beam Epitaxy," to be published, Elsevier Press (1983).

6. Poate, J. M. and Bean, J. C., Epitaxy of Deposited Silicon", Chap 8, Laser and Electron Beam Processing of Semiconductor Structures, J. M. Poate and J. W. Mayer eds, Academic Press New York (1982).

7. Shiraki, Y., "Recent Japanese Developments in Si MBE," Proc. 2nd Int. Symp. Molecular Beam Epitaxy and Related Clean Surface Techniques (Tokyo, 1982).

8. Shiraki, Y., "Silicon Molecular Beam Deposition," Physics and Technology of MBE, E. H. C. Parker and M. G. Dowsett (eds), to be published.

\section{EARLY RESEARCH}

9. Arbink, H. C., Broudy, R. M., and McCarthy, G..P., "Surface Processes in the Growth of Silicon on (111) Silicon in Ultrahigh Vacuum," J. Appl. Phys. 39, 4673 (1968).

10. Bicknell, R. W., Joyce, B. A., Neave, J. H., and Smith, G. V., "The Epitaxy of Silicon on Alumina-Structural Effects," Phil. Mag. 14, 31 (1966).

11. Booker, G. R. and Howie, A., "Intrinsic-Extrinsic Stacking-Fault Pairs in Epitaxially Grown Silicon Layers," Appl. Phys. Lett. 3, 156 (1963).

12. Booker, G. R. and Stickler, R., "Origin of Stacking Fault in Epitaxially Grown Silicon," Appl. Phys. Lett. 3, 158 (1963).

13. Booker, G. R., Crystallographic Imperfections in Silicon, Disc. Faraday Soc. 38, 298 (1964).

14. Booker, G. R. and Unvala, B. A., "Vacuum Evaporated Silicon Layers Free from Stacking Faults," Phil. Mag. 9, 1597 (1964).

15. Booker, G. R., Joyce, B. A., and Bradley, R. R., "Perfection of Epitaxial Silicon Layers Grown by Prolysis of Silane, "Phil. Mag. 10, 1087 (1964).

16. Booker, G. R. and Unvala, B. A., "Nucleation, Growth and Perfection of Epitaxial Silicon Layers," Vacuum 14, 123 (1964).

17. Booker, G. R. and Unvala, B. A., "Growth of Epitaxial Silicon Layers by Vacuum Evaporation. II: Initial Nucleation and Growth," Phil. Mag. 11, 11 (1965).

18. Booker, G. R., "Tripyramids and Associated Defects in Epitaxial Silicon Layers," Phil. Mag. 11, 1007 (1965)

19. Booker, G. R. and Valdre, V., "Observations of Silicon at High Temperature by Transmission Electron Microscopy," Phil. Mag. 13, 421 (1966).

20. Booker, G. R. and Joyce, B. A., "A Study of Nucleation in Chemically Grown Epitaxial Silicon Films Using Molecular Beam Techniques. II: Initial Growth Behavior on Clean and Carbon Contaminated Silicon Substrates, Phil. Mag. 14, 301 (1966). 
21. Booker, G. R., "Stacking Fault Defects in Epitaxial Silicon Layers," J. Appl. Phys. 37, 441 (1966).

22. Cullis, A. G. and Booker, G. R., "The Epitaxial Growth of Silicon and Germanium Films on (111) Silicon Surfaces Using UHV Sublimation and Evaporation Techniques," J. Cryst. Growth 9, 132 (1971).

23. Filby, J. D. and Nielsen, S., "Low Temperature Epitaxy of Silicon by Sublimation onto Thin Alloy Layers," J. Electrochem. Soc. 112, 535 (1965).

24. Filby, J. D., Nielsen, S., Rich, G. J., Booker, G. R., and Archer, J. M., "Investigation of Epitaxial Silicon Layers Grown in the Presence of Small Qunatities of Gold, " Phil. Mag. 16, 595 (1967).

25. Hale, A. P., "Preparation and Evaluation of Epitaxial Silicon Films Prepared by Vacuum Evaporation," Vacuum 13, 93 (1963).

26. Handelmann, E. and Povilonis, E. I., "Epitaxial Growth of Silicon by Vacuum Sublimation," J. Electrochem. Soc. 111, 201 (1964).

27. Joyce, B. A. and Bradley, R. R., "A Study of Nucleation in Chemically Grown Epitaxial Silicon Films Using Molecular Beam Techniques. I: Experimental Methods, Phil. Mag. 14, 289 (1966).

28. Joyce, B. A., Bradley, R. R, and Booker, G. R., "A Study of Nucleation in Chemically Grown Epitaxial Silicon Films Using Molecular Beam Techniques. III: Nucleation Rate Measurements and the Effect of Oxygen on Initial Growth Behavior," Phil. Mag. 15, 1167 (1967).

29. Joyce, B. A., Bradley, R. R., Watts, B. E., and Booker, G. R., "A Study of Nucleation in Chemically Grown Epitaxial Silicon Films Using Molecular Beam Techniques. V: Nucieation Kinetic Measurements on (100) Surfaces, " Phil. Mag. 19, 403 (1969).

30. Joyce, B. A., Neave, J. H., and Watts, B. E., "The Influence of Substrate Surface Conditions on the Nucleation and Growth of Epitaxial Silicon Films," Surf. Sci. 15, 1 (1969).

31. Nannichi, Y., "Epitaxial Growth of Silicon by Vacuum Sublimation," Nature 200, 1087 (1963).

32. Shewchun, J. and King, F. D., "Gas Doping of Vacuum Evaporated Epitaxial Silicon Films," Solid State Electronics 15, 775 (1972).

33. Thomas, D. J. D., "Growth and Structure of Evaporated Silicon Layers," Phys. Stat. Sol. 13, 359 (1966).

34. Thomas, R. N. and Francombe, M. H., "A LEED Study of the Homoepitaxial Growth of Thick Silicon Films," Appl. Phys. Lett. 11, 108 (1967).

35. Thomas, R. N. and Francombe, M. H., "A New Mechanism for Stacking Fault Generation in Epitaxial Growth of Silicon in Ultra-High Vacuum," Appl. Phys. Lett. 11, 134 (1967).

36. Thomas, R. N. and Francombe, M. H., "Low-Temperature Epitaxial Growth of PN Junctions by UHV Sublimation," Appl. Phys. Lett. 13, 270 (1968).

37. Thomas, R. N. and Francombe, M. H., "Low-Temperature Epitaxial Growth of Doped Silicon Films and Junctions," Sol. St. Elec. 12, 799 (1969).

38. Thomas, R. N. and Francombe, M. H., "Influence of Impurities on the Surface Structures and Fault Generation in Homoepitaxial Si (111) Films, "Surf. Sci. 25, 357 (1971).

39. Unvala, B. A., "Epitaxial Growth of Silicon by Vacuum Evaporation," Nature 194, 966 (1962).

40. Unvala, B. A. and Booker, G. R., "Growth of Epitaxial Silicon Layers by Vacuum Evaporation. I: Experimental Procedure and Initial Assessment," Phil. Mag. 9, 691 (1964).

41. Watts, B. E., Bradley, R. R., Joyce, B. A., and Booker, G. R., "A Study of Nucleation in Chemically Grown Epitaxial Silicon Films Using Molecular Beam Techniques. IV: Additional Confirmation of the Induction Period and Nucleation Mechanisms," Phil. Mag. 17, 1163 (1968). 
42. Weisberg, L. R., "Low Temperature Vacuum Deposition of Homoepitaxial Silicon," J. Appl. Phys. 38, 4537 (1967).

43. Widmer, H., "Epitaxial Growth of Si in Ultra High Vacuum," Appl. Phys. Lett. 5, 108 (1964).

See also reference(s) $68,74,75,80-84,90,94,106,124,140,141,144-150,153$

\section{APPARATUS}

44. Bean, J. C. and Sadowski, E. A., "Silicon MBE Apparatus for Uniform High-Rate Deposition on Standard Format Wafers," J. Vac. Sci. Technol. 20, 137 (1982).

45. Becker, G. E., "Operation of a Cryopumped UHV System," J. Vac. Sci. Technol. 14, 640 (1977).

46. Koenig, U., Herzog, H. J., Jorke, H., Kasper, E., and Kibbel, H., "Si-MBE with a High Throughput of Large Diameter Wafers," Proc. 2nd Int. Symp. Molecular Beam Epitaxy and Related Clean Surface Techniques (Tokyo, 1982).

47. Shimizu, S., Yoshikawa, H., Kiriya, M., and Komiya, S., "Monitoring of Deposition Rates of Multi-Component During Molecular Beam Epitaxial Growth of Silicon on Silicon (100) Using Atomic Absorption Spectroscopy," Vide-Couches Minces 201, 534 (1980).

48. Sugiura, H., "Simple, High Current, Antimony Ion Source," Rev. Sci. Instrum. 50, 84 (1979).

See also reference(s) $2,8,78,107,110$.

IV. SUBSTRATE PREPARATION

49. Bean, J. C., Becker, G. E., Petroff, P. M., and Seidel, T. E., "Dependence of Residual Damage on Temperature During Ar+ Sputter Cleaning of Silicon," J. Appl. Phys. 48, 907 (1977).

50. Henderson, R. C., "Silicon Cleaning with Hydrogen Peroxide Solutions: A High Energy Electron Diffraction and Auger Electron Spectroscopy Study," J. Electrochem. Soc. 119, 772 (1972).

51. Henderson, R. C. and Helm, R. F., "Silicon Homoepitaxial Thin Films Via Silane Pyrolsis: A HEED and Auger Electron Spectroscopy Study," Surf. Sci. 30, 310 (1972).

52. Ishizaka, A., Nakagawa, K., and Shiraki, Y., "Low Temperature Surface Cleaning of Silicon and its Application to Silicon MBE." Proc. 2nd Int. Symp. Molecular Beam Epitaxy and Related Clean Surface Techniques, (Tokyo, 1982).

53. Jona, F., "Observation of "Clean". Surfaces of Si, Ge and GaAs by Low-Energy Electron Diffraction," IBM J. Res. Dev. 9, 375 (1965).

54. McFee, J. H., Swartz, R. G., Archer, V. D., Finegan, S. N., and Feldman, L. C., "A Quantitative Study of the Relationship Between Interfacial Carbon and Line Dislocation Density in Silicon Molecular Beam Epitaxy," to be publ. J. Electrochem. Soc.

55. Smit, L., De Jong, T., Hoohout, D., and Saris, F. W., "Silicon Molecular Beam Epitaxy on Arsenic-Implanted and Laser-Processed Silicon," Appl. Phys. Lett. 40, 64 (1982).

56. Sugiura, H. and Yamaguchi, M., "Crystal Defects of Silicon Films Formed by Molecular Beam Epitaxy, " Jpn. J. Appl. Phys. 19, 583 (1980).

57. Sugiura, H. and Yamaguchi, M., "Growth of Dislocation-Free Silicon Films by Molecular Beam Epitaxy (MBE)," J. Vac. Sci. Technol. 19, 157 (1981).

58. Wright, S. and Kroemer, H., "Reduction of Oxides on Silicon by Heating in a Gallium Molecular Beam at $800^{\circ} \mathrm{C}$," Appl. Phys. Lett. 36, 210 (1980).

59. Yamada, I., Marton, D., and Saris, F. W., "Residual Damage to an Atomically Cleaned Low-Temperature Si (100) Surface," Appl. Phys. Lett. 37, 563 (1980).

60. Yamamoto, Y., Shinada, K., Itoh, T., and Yada; K., "Damage in the Surface Region of Silicon Produced by Sputter-Etching," Jap. J. Appl. Phys. 13, 551 (1974). 
61. Zehner, D. M., White, C. W., and Ownby, G. W., "Preparation of Atomically Clean Silicon Surfaces by Pulsed Laser Irradiation," Appl. Phys. Lett. 36, 56 (1980).

See also reference(s) 120 .

\section{HOMOEPITAXY}

\section{A. UNDOPED OR WITH EVAPORATED DOPANTS}

62. Aleksandrov, L. N., Lovyagin, R. N., Saprykin, A. I., and Novik, V., "Background and Dopant Impurities in Semiconducting Films and in the Film-Substrate Transition Region During Epitaxy from Molecular Beams," Inorg. Mater. 16, 783 (1980).

63. Arushanov, A. Y., Gridneva, G. N., and Paramonova, R. A., "Investigating the Condition for the Migration of Impurities from the Ingot During the Doping of Epitaxial Layers of Silicon Obtained by Condensation from Molecular Beams in a Very High Vacuum," Poluprovoch. Tekh. and M. Kroelekhon 31, 31 (1980).

64. Allen, F. G., Iyer, S. S., and Metzger, R. A., "Dopant Incorporation Studies in Silicon Molecular Beam Epitaxy," to be publ. Applications of Surf. Sci. (1982).

65. Becker, G. E. and Bean, J. C., "Acceptor Dopants in Silicon Molecular Beam Epitaxy," J. Appl. Phys. 48, 3395 (1977).

66. . Bean, J. C., "Arbitrary Doping Profiles Produced by Antimony-Doped Silicon MBE," Appl. Phys. Lett. 33, 654 (1978).

67. Bean, J. C., "Silicon MBE," J. Vac. Sci. Technol. 18, 769 (1981).

68. Bennett, R. J. and Gale, G. W., "Kinetics of the Induction Period for the Nucleation of Silicon on (111) Silicon Substrates at UHV," Phil. Mag. 22, 135 (1970).

69. Bennett, R. J. and Parish, C., "Control of Impurity Density in Homoepitaxial Semiconductor Layers Grown by Sublimation at UHV," Sol. St. Elec. 16, 497 (1973)

70. Bennett, R. J. and Parish, C., "Determination of Diffusion, Partition and Sticking Coefficients for Boron, Phosphorus and Antimony in Silicon, Sol. St. Elec. 18, 833 (1975).

71. Chernov, A. A. and Rusaikin, M. P., "Capture of Impurities by Crystal Growth from a Gas Phase when the Substance is Asymmetrically Captured by Steps," Izv. Khim. Bulg. Akad. Nauk. 11, 576 (1978).

72. Gridneva, G. N. and Paramonova, R. A., "The Electro-physical Properties of Epitaxial Layers of Silicon Produced by the Condensation Method from Molecular Beams in a Vacuum," Poluprovodn. Tekh. and Mikroelektron 30, 64 (1979).

73. Iyer, S. S., Metzger, R. A., and Allen, F. G., "Sharp Profiles with High and Low Doping Levels in Silicon Grown by Molecular Beam Epitaxy," J. Appl. Phys. 52, 5608 (1981).

74. Jona, F., "Study of the Early Stages of the Epitaxy of Silicon on Silicon," Appl. Phys. Lett. 9, 235 (1966).

75. Jona, F., "Ion-Energy-Electron Diffraction Study of the Epitaxy of $\mathrm{Si}$ on $\mathrm{Si}$," Chap. 18, Surfaces and Interfaces/Chemical and Physical Characteristics, J. J. Burke, N. L. Reed. and V. Weiss (eds), Syracuse Univ. Press (1967).

76. Kasper, E., "Molecular Beam Epitaxy of Silicon," Wiss. Ber. Aeg-Telefunken 52, 147 (1979).

77. Kasper, E., "Low-Temperature Epitaxy of Silicon by Molecular Beam Epitaxy (MBE)," Wiss. Ber. Aeg-Telefunken, 53, 170 (1980).

78. Koenig, V., Kibbel, H., and Kasper, E., "Silicon-MBE: Growth and Antimony Doping," J. Vac. Sci. Technol. 16, 985 (1979).

79. Koenig, V., Kasper, E., and Herzog, H. J., "Molecular Beam Epitaxy of Silicon: Effects of Heavy Antimony Doping," J. Cryst. Growth 52, 151 (1981).

80. Kuznetsov, V. P., Loginova, R. G., Ovsyannikov, M. I., and Postnikov, V. V., "Doping of Epitaxial Silicon Films During their Growth by Vacuum Sublimation," Protsessy Rosta Strukt. Monokrist. Sloev Poluprov., Tr. Simp. 1,483, (1968). 
81. Kuznetsov, V. P. and Postnikov, V. V., "Various Properties of Epitaxial Films of Si Obtained by Sublimation in Vacuum from Sources Doped with As and P," Sov. Phys.Cryst. 14, 441 (1969).

82. Kuznetsov, V. P., Postnikov, V. V., and Tolomasov, V. A., "Layers of Silicon Obtained by Vacuum Sublimation at $430-600^{\circ}$, Sov. Phys.-Cryst. 15, 335 (1970).

83. Kuznetsov, V. P. and Postnikov, V. V., "Determination of the Temperature of a Silicon Layer During its Growth on a Silicon Substrate," Zavod. Lab. 8, 977 (1970):

84. Kuznetsov, V. P., Rubtsova, R. A., Sergievskaya, T. N., and Postnikov, V. V., "Silicon Films Obtained by Vacuum Sublimation at $600-1000^{\circ} \mathrm{C}$ from Sources Doped with Phosphorus, Arsenic and Antimony," Sov. Phys.-Cryst. 16, 357 (1971).

85. Kuznetsov, V. P. and Postnikov, V. V., "Transfer of the Impurities $\mathrm{P}$, As and $\mathrm{Al}$ from Silicon Sources into Films Obtained by Vacuum Sublimation," Sov. Phys.-Cryst. 19, 211 (1974).

86. Kuznetsov, V. P., Postnikov, V. V., Komrakova, T. D., Rozanova, E. A., Strizheva, T. N., and Zotova, T. M., "Laws Governing the Formation of Defects in Silicon Layers Grown by Sublimation at $440-1000^{\circ} \mathrm{C}$ In Vacuo," Sov. Phys.-Cryst. 20,382 (1975).

87. Kuznetsov, V. P., Tolomasov, V. A., Shmenina, T. M., and Gudkova, N. V., "An Electron-Microscopic Investigation of Silicon Layers Grown by Sublimation in Vacuum," Sov. Phys.-Cryst. 23, 371 (1978).

88. Kuznetsov, V. P., Tolomasov, V. A., and Tumanova, A. N., "Doping of Thin Epitaxial Si . Layers Grown in Vacuum at Low Temperatures," Sov. Phys.-Cryst. 24, 588 (1979).

89. Kuznetsov, V. P. and Tolomasov, V. A., "Nucleation of Stacking Faults in Silicon Layers Grown in a Vacuum, "Sov. Phys.-Cryst. 26, 369 (1981).

90. Narusawa, T. and Komiya, S., "LEED (Low Energy Electron Diffraction) and Auger Electron Spectroscopic Observations of the Substrate Surface During Sputtering and Vacuum Vapor Deposition, Vacuum," 22, 349 (1972).

91. Narusawa, T., Shimizu, S., and Komiya, S., "Simultaneous RHEED/AES Study of Silicon Film Growth on Silicon (111) and Sapphire (1102) Surfaces," Surf. Sci. 86, 572 (1979).

92. Ota, Y., "Silicon Molecular Beam Epitaxy (n on $\mathrm{n}^{+}$) with Wide Range Doping Control," J. Electrochem. Soc. 124, 1795 (1977).

93. Perov, A. S. and Postnikov, V. V., "Principles of Doping a Silicon Crystal During Growth from an Atomic Beam in a Vacuum,". Izv. Vyssh. Vchebn. Zaved., Fiz. 25, 24 (1982).

94. Postnikov, V. V., Ovsyannikov, M. I., Loginova, R. G., Rubtsova, R. A., Sergievskaya, T. N., Tolomasov, V. A., "Epitaxial Silicon Layers Obtained by Sublimation in Vacuo," Dokl. Akad. Nauk SSSR, 175, 817 (1967).

95. Postnikov, V. V. and Kuznetsov, V. P., "Transport of Donor and Acceptor Impurities from a Sublimating Silicon Source into the Epitaxial Layer," Sov. Phys.-Cryst. 20, 71 (1975).

96. Postnikov, V. V. and Perov, A. S., "Effect of Free Carriers on the Transport of a Doping Impurity into Epitaxial Films Derived from Molecular Flows in Vacuo," Sov. Phys.-Cryst. 22, 350 (1977).

97. Postnikov, V. S., Shvedov, E. V., and Ievlev, V. M., "Kinetic Model of Oriented Growth of Nucleating Centres During Vacuum Condensation, ${ }^{, ~ F i z . ~ a n d ~ K h i m . ~ O b r a b . ~ M a t e r ~ 1, ~ 77 . ~}$ (1979).

98. Perov, A. S. and Postnikov, V. V., "Effect of Free Carriers on the Distribution of a Doping Impurity in Epitaxial Layers Obtained from Molecular Flow in Vacuo," Sov. Phys.-Cryst. 22, 475 (1977).

99. Sakamoto, T., Takahashi, T., Suzuki, E., Shoji, A., Kawanami, H., Komiya, Y., and Tarai, Y., "Si Epitaxy by Molecular Beam Method," Surf. Sci. 86, 102 (1979).

100. Sakamoto, T. and Kawanami, H., "RHEED Studies of Si (100) Surface Structures Induced by Ga Evaporation," Surf. Sci. 111, 177 (1981). 
101, Shih, H. D., Jona, F., Jepsen, D. W., and Marcus, P. M., "Low-Energy Electron Diffraction Determination. of the Atomic Arrangement on Impurity-Stabilized Unreconstructed Si $\{100\}$ Surfaces," Phys. Rev. Lett. 37, 1622 (1976).

102. Shiraki, Y., Katayama, Y., Kobayashi, K. L. I., and Komatsubara, K. F., "Molecular Beam and Solid-Phase Epitaxies of Silicon Under Ultra-High Vacuum," J. Cryst. Growth 45, 287 (1978).

103. Tabe, M., Arai, K., and Nakamura, H., "Effect of Growth Temperature on Si MBE Film," Jap. J. Appl. Phys. 20, 703 (1981).

104. Tabe, M. and Kajiyama, K., "Kinetics of Antimony Doping in Silicon MBE," Proc. 2nd Int. Symp. on Molecular Beam Epitaxy and Related Clean Surface Techniques," (Tokyo 1982).

105. Theeten, J. B., "Real-Time and Spectroscopic Ellipsometry of Film Growth: Application to Multilayer Systems in Plasma and CVD Processing of Semiconductors, "Surf. Sci. 96, 275 (1982).

106. Tolomasov, V. A., Abrosimova, L. N., and Gorshenin, G. N., "Epitaxial Films of n-type Silicon Obtained by Vacuum Sublimation," Sov. Phys.-Cryst. 15, 1076 (1971).

See also reference(s) 107, 130, 134, 195-201, 203, 204.

\section{B. IMPLANTED DOPANTS}

107. Ota, Y., "N-Type Doping Techniques in Silicon Molecular Beam Epitaxy by Simultaneous Arsenic Ion Implantation and by Antimony Evaporation," J. Electrochem. Soc. 126, 1761 (1979).

108. Ota, Y., "Silicon Molecular Beam Epitaxy with Simultaneous Ion Implant Doping," J. Appl. Phys. 51, 1102 (1980).

109. Ota, Y., "Ion Implanted Silicon Molecular Beam Epitaxy ( ${ }^{2}$ Silicon MBE)," Proc. Conf. Solid State Devices 11, 637 (1980).

110. Sugiura, H., "A Method of Si Vacuum Deposition Combined with Sb Ion Implantation," J. Vac. Soc. Jpn. 21, 80 (1978).

111. Sugiura, H., "A Method of Silicon Vacuum Deposition Combined with Antimony Ion Implantation," Shinky 21, 80 (1978).

112. Sugiura, H., "Study of Method Combined with Silicon Vacuum Deposition and Antimony Ion Implantation," Electr. Commun. Lab. Tech. J. 27, 1329 (1978).

113. Sugiura, H., "A Method of Silicon Vacuum Deposition Combined with Antimony Ion Implantation," Rev. Electr. Commun. Lab. 27, 130 (1979).

114. Sugiura, H., "Doping Profile Control in Silicon MBE Film with Antimony Ion Doping," Proc. Conf. Solid State Devices, 11 th, 641 (1980); Jap. J. Appl. Phys. 19, (Suppl. 19-1), 641 (1980).

115. Sugiura, H., "Silicon Molecular Beam Epitaxy with Antimony Ion Doping," J. Appl. Phys. 51,2630 (1980).

116. Sugiura, H. and Yamaguchi, M., "Si Molecular Beam Epitaxy with Ion Doping," J. Vac. Soc. Jpn. 23, 520 (1980).

117. Sugiura, H. and Yamaguchi, M., "Silicon MBE with Ion Doping," Iongen to Ion Kiso Toshita Oyo Gijutsu, Shinpojumu, 5th, 329 (1981).

118. Swartz, R. G., McFee, J. H., Voshchenkov, A. M., Finegan, S. N., Archer, V. D., and O'Day, P. J., "In-Situ Low Energy BF $_{2}^{+}$Ion Doping for Silicon Molecular Beam Epitaxy," Elec. Dev. Lett. EDL-3, 138 (1982).

119. Swartz, R. G., McFee, J. H., Voshchenkov, A. M., Finegan, S. N., and Ota, Y., "A Technique for Rapidly Aiternating Boron and Arsenic Doping in Ion-Implanted Silicon Molecular Beam Epitaxy," Appl. Phys. Lett. 40, 239 (1982).

See also reference(s) 44, 48, 132, 133, 204. 


\section{IONIZED SILICON DEPOSITION}

120. Aleksandrov, L. N., Lutovich, A. S., and Belorusets, E. D., "The Mechanism of Silicon Epitaxial Layer Growth from Ion Molecular Beams," Phys. Status. Solidi A 54, 463 (1979).

121. Bouchier, D., Fallot, I. L., Gautherin, G., Vapaille, A., Dagoury, M., and Rousseau, B., "Fabrication of Epitaxial Layers Using Ion Beam Sputtering," Vide 182, (1976).

122. Gautherin, G. and Weissmantel, Chr., "Some Trends in Preparing Film Structures by Ion Beam Methods," Thin Solid Films 50, 135 (1978).

123. Hinneberg, H. J., Weidner, M., Hecht, G., and Weissmantel, C., "Electrical Properties of Ion Beam Sputtered Silicon Layers on Spinel," Thin Solid Films 33, 29 (1976).

124. Itoh, T. and Nakamura, T., "Epitaxial Growth of Silicon Assisted by Ion Implantation," Radiat. Eff. 9, 1 (1971).

125. Itoh, T., Nakamura, T., Muromachi, M., and Sugiyama, T., "Antimony Concentration in Silicon Epitaxial Layer Formed by Partially Ionized Vapor Deposition," Jap. J. Appl. Phys. 15, 1145 (1976).

126. Itoh, T., Nakamura, T., Muromachi, M., and Sugiyama, T., "Low Temperature Silicon Epitaxy by Partially Ionized Vapor Deposition," Jpn. J. Appl. Phys. 16, 553 (1977).

127. Morimoto, K., Watanabe, H., and Itoh, S., "Ionized-Cluster Beam Epitaxial Growth of GaP Films on GaP and Si Substrates," J. Cryst. Growth 45, 334 (1978).

128. Narusawa, T., Shimizu, S., and Komiya, S., "Simultaneous RHEED-AES-QMS Study on Epitaxial Silicon Film Growth on Silicon (111) and Sapphire (1) 102$)$ Surfaces by Partially Ionized Vapor Deposition, J. Vac. Sci. Technol. 16, 366 (1979).

129. Schwebel, C., Vapaille, A., Bouchier, D., Gautherin, G., and Meyer, F., "Semiconductor Epitaxy (Obtained) by Ion Beam Sputtering," Vide-Couches Minces 196, 361 (1979).

130. Schwebel, L. C., Vapaille, A., Bouchier, D., Gautherin, G., and Meyer, F., "Silicon Homo and Heteroepitaxy by Ion Beam Sputtering," Vide-Couches Minces 201, 125 (1980).

131. Shimizu, S. and Komiya, S., "Epitaxial Growth of Silicon on (1012) Aluminum Oxide by Partially Ionized Vapor Deposition," J. Vac. Sci. Technol. 17, 489 (1980).

132. Shimizu, S. and Komiya, S., "The Effects of Low-Energy Ions in Silicon Molecular Beam Deposition," Iongen to Ion Kiso Toshita Oyo Gijutsu, Shinpojumu, 5th, Toshinori Takagi (ed), p. 435 (1981).

133. Shimizu, S. and Komiya, S., "Effects of Ga and Si Ionization on the Growth of Ga Doped Si MBE," J. Vac. Sci. Technol. 18, 765 (1981).

134. Sugiyama, T., Shimada, O., and Itoh, T., "On the Doping Efficiency of Ga or Sb into Silicon Epitaxial Films Grown by Part Ionized Vapor Deposition," J. Vac. Soc. Jpn. 21, 386 (1978).

135. Weissmantel, C., Hecht, G., and Hinneburg, H. J., "Deposition of Epitaxial Layers by Ion Beam Methods," J. Vac. Sci. Technol. 17, 812 (1980).

136. Weissmantel, C., Breuer, K., Erben, J. W., Nowick, W., and Scharff, W., "GraphoEpitaxy by Using Partially Ionized Particle Beams," Proc. 2nd Int: Symp. Molecular Beam Epitaxy and Related Clean Surface Techniques (Tokyo, 1982).

137. Yamada, I., Matsubara, K., Kodama, M., Ozawa, M., and Takagi, I., "Characteristics of Thin Films Formed by the Ionized-Cluster Beam Technique," J. Cryst. Growth 45, 326 (1978).

138. Zalm, P. C. and Beckers, L. J., "Ion Beam Epitaxy of Silicon on Ge and Si at Temperatures of 400K," Appl. Phys. Lett. 41, 167 (1982). 


\section{HETEROEPITAXY}

\section{A. - INSULATING SUBSTRATES}

139. Bean, J. C., "Growth of Thin Silicon Films on Sapphire and Spinel by Molecular Beam Epitaxy," Appl. Phys. Lett. 36, 741 (1980).

140. Chang, C. C., "LEED Studies of Thin Film Silicon Overgrowths on $\alpha$-Alumina," in The Structure and Chemistry of Solid Surfaces, Gabor A. Somorjai (ed), John Wiley \& Sons, Inc. (1969), p. 77-1.

141. Chang, C. C., "Silicon-on-Sapphire Epitaxy by Vacuum Sublimation: LEED-Auger Studies and Electronic Properties of the Films," J. Vac. Sci. Tech. 8, 500 (1971).

142. Ecke, W. and Duda, P., "Das Dotieren Aufgedampfter Heteroepitakischer Siliziumschichten," Kryst. Technik. 12, 447 (1977).

143. Ecke, W., "The Photomagnetoelectric Effect in Heteroepitaxial Silicon Films," Phys. Stat. Sol. 42A, 157 (1977).

144. Gassman, F., Della Case, A., and Aeschlimann, R., "Epitaxiale Siliziumschichten auf Spinell Durch Aufdampfen in Ultra-Hoch Vakum," Mater. Res. Bull. 6, 817 (1971).

145. Gassman, F., Aeschlimann, F. R., and Banziger, U., "Eigenschaften Epitaxialer Siliziumschichten auf Spinell vor und nach dem Oxidieren, ${ }^{n}$ Mater. Res. Bull. 7, 1493 (1972).

146. Hasegawa, S., Kaminaka, N., Nakamura, T., and Itoh, T., "Analysis of Carrier Transport in Vacuum-Evaporated Epitaxial Films of Silicon on Spinel," J. Appl. Phys. 40, 4620 (1969).

147. Itoh, T., "Silicon on Sapphire Structure," Oyo Butsuri 36, 554 (1967).

148. Itoh, T., Hasegawa, S., and Watanabe, H., "Epitaxial Films of Silicon on Sapphire Formed by Vacuum Evaporation and their Electrical Properties," J. Appl. Phys. 39, 2969 (1968)

149. Itoh, T., Hasegawa, S., and Kaminaka, N., "Electrical Properties of n-type Epitaxial Films of Silicon on Sapphire Formed by Vacuum Evaporation," J. Appl. Phys. 39, 5310 (1968).

150. Itoh, T., Hasegawa, S., and Kaminaka; N., "Epitaxial Films of Silicon on Spinel by Vacuum Evaporation, " J. Appl. Phys. 40, 2597 (1969).

151. Konaka, S., Tabe, M., and Sakai, T., "A New Silicon on Insulator Structure Using a Silicon Molecular Beam Epitaxial Growth on Porous Silicon," Appl. Phys. Lett. 41, 86 (1982).

152. Takai, H. and Itoh, T., "Silicon Epitaxial Growth on Sapphire by Plasma Dissociation Method," Iongen to Sono Oyo, Shinpojumu, 4th (1980), p. 151.

153. Yasuda, Y., "Epitaxial Growth of Silicon Films on Sapphire and Spinel by Vacuum Evaporation," Jap. J. Appl. Phys. 10, 45, (1971).

See also reference(s) $10,91,123,128,131$.

\section{B. INSULATOR/SILICON GROWTH}

154. Asano, T. and Ishiwara, H., "Formation of an Epitaxial Silicon/Insulator/Silicon Structure by Vacuum Deposition of Calcium Fluoride and Silicon," Jpn. J. Appl. Phys., Part 1, 21, 187 (1982).

155. Harrison, T. R., Mankiewish, P. M., and Dayem, A. H., "A Thin Film CaF 2 Inorganic Electron Resist and Optical-Read Storage Medium," to be publ. Appl. Phys. Lett.

156. Ishiwara, H. and Asano, T., "Silicon/Insulator Heteroepitaxial Structures Formed by Vacuum Deposition of Calcium Fluoride and Silicon," Appl. Phys. Lett. 40, 66 (1982).

157. Yoshida, S., Misawa, S., Fujii, Y., Takada, S., Hayakawa, H., Gonda, S., and Itoh, A., "Reactive Molecular Beam Epitaxy of Aluminum Nitride," J. Vac. Sci. Technol. 16, 990 (1979).

\section{METAL/SILICON GROWTH}

158. Baba, S., Jun Ming Zhou., and Kinbara, A., "Super-structures and Growth Properties of Indium Deposits on Silicen (111) Surfaces with its Influence on Surface Electrical Conduction," Jpn. J. Appl. Phys. 19, L571 (1980). 
159. Bean, J. C. and Poate, J. M., "Silicon/Metal Silicide Heterostructures Grown by Molecular Beam Epitaxy," Appl. Phys. Lett. 37, 643 (1980).

160. Gibson, J. M., Bean, J. C., Poate, J. M., and Tung, R. T., "Analysis of Cobalt Silicide $\left(\mathrm{CoSi}_{2}\right)$-Silicon Heterostructures and Interfaces," Conf. Ser.-Inst. Phys. 60, 415 (1981).

161. Gibson, J. M., Bean, J. C., Poate, J. M., and Tung, R. T., "Effects of Nucleation and Growth on Epitaxy in the $\mathrm{CoSi}_{2} / \mathrm{Si}$ System," Proc. 1981 Materials Res. Soc. Meet. to be publ. Thin Solid Films.

162. Gibson, J. M., Bean, J. C., Poate, J. M., and Tung, R. T., "Atomic Structure at a SingleCrystal Metal/Semiconductor Interface by High-Resolution Electron Microscopy Proc 10th Int. Conf. on Electron Microscopy Hamburg 1982.

163. Harrison, T. R., "Lattice Structure in Ni-Si Coevaporated Films," to be publ. J. Appl. Phys.

164. Harrison, T. R., Johnson, A. M., Tien, P. K., and Dayem, A. H., "NiSi ${ }_{2}-\mathrm{Si}_{\text {Infrared }}$ Schottky Photodetectors Grown by Molecular Beam Epitaxy," to be publ. Appl. Phys. Lett.

165. Hikosaka, K., Ishiwara, H., and Furukawa, S., "Annealing Behavior of Radiation Damages in Metal-Silicides," Radiat. Eff. 51, 253 (1980).

166. Ishiwara, H., Hikosaka, K., and Furukawa, S., "Channeling and Backscattering Studies of the Crystalline Perfection and the Thermal Stability of Epitaxial PtSi Films on Si, $J$. Appl. Phys. 50, 5302 (1979).

167. Ishiwara, H., Saitoh, S., and Furukawa, S., "Control of Solid Phase Epitaxial Growth in the Pd-Si System by Carbon Ion Implantation," Jpn. J. Appl. Phys. 19, 831 (1980).

168. Ishiwara, H., Nagatomo, M., and Furukawa, S., "A Structure Modeling of Metal-Silicide Layers by Using Axial and Planar Channeling Techniques," Nucl. Instrum. Methods 149, 417 (1978).

169. Ishiwara, H., Hikosaka, K., Nagatomo, M., and Furukawa, S., "Characterization of Epitaxial Metal Silicide Films Grown on Silicon," Surf. Sci. 86, 711 (1979),

170. Ishiwara, H., "Characterization of Epitaxial Silicide Films," Proc. Symp. Thin Film Interfaces p. 159 (1979).

171. Kawajii, M., Baba, S., and Kinbara, A., "Reflection High Energy Electron Diffraction Investigation of Indium and Antimony Deposited by Molecular Beam Epitaxy," Thin Solid Films 58, 183 (1979).

172. Kawazu, A., Saito, Y., Ogiwara, N., Otsuki, T., and Tomunaga, G., "Kinetics of Deposition of Bismuth Film by a Molecular Beam Method," Surf. Sci. 86, 108 (1979).

173. Nagatomo M., Ishiwara, H., and Furukawa, S., "Studies on Formation Characteristics and Mechanism of SiC on Si and Metal-Silicides by Using Ion Backscattering Techniques," Jpn. J. Appl. Phys. 18, 765 (1979).

174. Saitoh, S., Ishiwara, H., and Furukawa, S., "Double Heteroepitaxy in the Si (111)/CoSi 2 /Si Structure," Appl. Phys. Lett. 37, 203 (1980).

175. Saitoh, S., Ishiwara, H., and Furukawa, S., "Formation of a Double-Hetero $\mathrm{Si} / \mathrm{CoSi}_{2} / \mathrm{Si}$ Structure Using Molecular Beam and Solid Phase Epitaxies, Jpn. J. Appl. Phys. 20, 49 (1981).

176. Saitoh, S., Ishiwara, H., Asano, T., and Furukawa, S., "Single Crystalline Silicide Formation," Jpn. J. Appl. Phys. 20, 1649 (1981).

177. Tung, R. T., Poate J. M., Bean, J. C., Gibson, J. M., Jacobson, D. C., "Epitaxial Silicides" Proc. 1981 Materials Res. Soc. Meet, to be published Thin Solid Films.

178. Tung, R. T., Bean, J. C., Gibson, J. M., Poate, J. M., and Jacobson, D. C., "Growth of Single Crystal Cobalt Disilicide on Silicon (111)," Appl. Phys. Lett. 40, 684 (1982).

\section{SEMICONDUCTOR/SILICON GROWTH}

179. Gonda, S., Matsushima, Y., Mukai, S., Nakita, Y., and Igarashi, O., "Heteroepitaxial Growth of GaP on Silicon by Molecular Beam Epitaxy," Jpn. J. Appl. Phys. 17, 1043 (1978). 
180. Kasper, E., Herzog, H. J., and Kibbel, H., "One-Dimensional Silicon Germanide Superlattice Grown by UHV (Ultra-High Vacuum) Epitaxy," Appl. Phys. 8, 199 (1975).

181. Kasper, E. and Pabst, W., "Profiling of Silicon-Germanium Alloy Superlattices by Helium Backscattering," Thin Solid Films 37, L5 (1976).

182. Kasper, E. and Herzog, H. J., "UHV Epitaxial of Si and SiGe Onto Si Substrates," Wiss. Ber. Aeg-Telefunken 49, 213 (1976).

183. Kasper, E. and Herzog, H. J., "Elastic Strain and Misfit Dislocation Density in Silicon Germanide $\left(\mathrm{Si}_{0.92} \mathrm{Ge}_{0.08}\right.$ ) Films on Silicon Substrates," Thin Solid Films 44, 357 (1977).

184. Kawanami, H., Sakamoto, T., Takahashi, T., Suzuki, E., and Nagai, Kiyoko, "Heteroepitaxial Growth of Gallium Phosphide on a Silicon (100) Substrate by Molecular Beam Epitaxy," Jpn. J. Appl. Phys. 21, L68 (1982).

185. Madhukar, A. and Delgado, J., "The Electronic Structure of Si/GaP (110) Interface and Superlattice," Solid State Commun. 37, 199 (1981).

186. Vasilevskaya, V. N., Datsenko, L. I., Osadchaya, N. V., Prokopenko, I. V., Soldatenko, N. N., and Tkhorik, Yu. A., "Structural Perfection of Heterojunctions of GermaniumSilicon," Defekty Strukt. Poluprovoch. 73, 80 (1974).

187. Vasilevskaya, V. N., Datsenko, L. I., Osadchaya, N. V., Prokopenko, I. V., Soldatenko, N. N., and Tkhorik, Yu. A., "Structural Perfection of the Germanium-Silicon and Silicon-Germanium Heteroepitaxial Systems," Thin Solid Films 22, 221 (1974).

188. Vasilevskaya, V. N., Datsenko, L. I., Osadchaya, N. V., Torchun, N. M., Tkhorik, Yu. A., and Fedotova, G. F., "Imperfections at the Interface of the Si-Ge Heteroepitaxial Structure," Poluprovodn. Tekh. and Mikroelektron. 18, 54 (1974).

189. Vasilevskaya, V. N., Datsenko, L. I., Prokopenko, I. V., Kislovskii, E. N., and Stadnik, A. V., "Crystal Perfection of the Germanium-Silicon Heteroepitaxial System," Poluprovodn. Tekh. Mikroelektron 14, 75 (1974).

190. Vasilevskaya, V. N., Konakova, R. V., Osadchaya, N. V., Tkhorik, Yu. A., Filatov, M. Yu., and Shvarts, Yu. M., "The Effect of Growth Conditions on the Structural and Electrical Properties of the Silicon-Germanium Heteroepitaxial System," Thin Solid Films 30, 91 (1975).

191. Vasilevskaya, V. N., Datsenko, L. I., Konakova, R. V., Osadchaya, N. V., and Shvarts, Y., "Imperfections in the Transient Layer of the Si-Si/Sub E/-Ge Heteroepitaxial System," Thin Solid Films 32, 371 (1976).

192. Vasilevskaya, V. N., Datsenko, L. I., Konakova, R. V., Osadchaya, N. V., Tkhorik, Yu. A., and Shvarts, Yu. M., "Defects in Silicon-Epitaxial Silicon-Germanium Structures," Rost i Legirovanie Poluprovodn. Kristallov Plenok, 2, 232 (1977).

193. Vasilevskaya, V. N., Konakova, R. V., Osadchaya, N. V., Tkhorik, Yu. A., Torchun, N. M., and Shvarts, Yu. M., "The Structure and Electrical Characteristics of Silicon/Germanium Heterojunctions, I. Imperfections in the Silicon-Germanium Heteroepitaxial System Obtained by Deposition of Germanium from a Molecular Beam," Thin Solid Films 55, 229 (1978).

See also reference(s) $127,138$.

\section{PATTERNED EPITAXY}

194. Bean, J. C. and Rozgonyi, G. A., "Patterned Silicon Molecular Beam Epitaxy with Submicron Lateral Resolution," to be published Appl. Phys. Lett.

\section{DEVICE STRUCTURES}

195. Ballamy, W. C. and Ota, Y., "Low Barrier Height Schottky Mixed Diode Using Super Thin Silicon Films by Molecular Beam Epitaxy," Appl. Phys. Lett. 39, 629 (1981).

196. Fowler, A. B., "Metal Subcollector Bipolar Transistor," IBM Tech. Disclosure Bull. 20, 1668 (1977).

197. Freyer, J., Kasper, E., and Barth, H., "Pulsed V-Band MBE Impatt Diodes," Electron. Lett. 16, 365 (1980). 
198. Goodwin, C. A. and Ota, Y., "Applications of Silicon MBE to Microwave Hyperabrupt Diodes," IEEE Trans. Electron Devices ED-26, 1796 (1979).

199. Kasper, E., "Series Resistance of Epitaxial Silicon Schottky Diodes," Wiss. Ber. AegTelefunken 52, 179 (1979).

200. Kasper, E., Barth, H., and Freyer, J., "Pulsed Silicon Impatt Diodes for Millimeter Wave Oscillators," Nachrichtentech. Z. 34, 768 (1981).

201. Katayama, Y., Shiraki, Y., Kobayashi, K. L. I., Komatsubara, K. F, and Hashimoto, N., "An MOS Field-Effect Transistor Fabricated on a Molecular-Beam Epitaxial Silicon Layer," Appl. Phys. Lett. 34, 740 (1979).

202. Matsui, M., Shiraki, Y., Katayama, Y., Kobayashi, K. L. I., Shintani, A., and Maruyama, E., "Polycrystalline Silicon Thin-Film Transistors on Glass," Appl. Phys. Lett. 37, 936 (1980).

203. Ota, Y., Buchanan, W. L., and Petersen, O. G., "MM-Wave PIN Switching Diode Fabrication using Silicon Molecular Beam Epitaxy," Tech. Dig.-Int. Electron Devices Meet. (1977), p. 375.

204. Swartz, R. G., McFee, J. H., Grabbe, P., and Finegan, S., "An Uncompensated Silicon Bipolar Junction Transistor Fabricated Using Molecular Beam Epitaxy," IEEE Electron Device Lett EDL-2, 293 (1981).

See also reference(s) $2,8,65,73$.

\section{$X$. NON-EPITAXIAL DEPOSITION}

205. Bean, J. C., Leamy, H. J., Poate, J. M., Rozgonyi, G. A., Sheng, T. T., Williams, J. S., and Celler, G. K., "Epitaxial Laser Crystallization of Thin-Film Amorphous Silicon," Appl. Phys. Lett. 33, 227 (1978).

206. Bean, J. C., Leamy, H. J., Poate, J. M., Rozgonyi, G. A., Van der Ziel, J. P., Williams, J. S., and Celler, G. K., "Substrate and Doping Effects Upon Laser-Induced Epitaxy of Amorphous Silicon," J. Appl, Phys. 50, 881 (1979).

207. Bean, J. C., Leamy, H. J., Poate, J. M., Rozgonyi, G. A., Van der Ziel, J. P., Williams, J. S., and Celler, G. K., "Laser Induced Epitaxy of Amorphous Deposited Silicon," AIP Conf. Proc. 50, 487 (1979).

208. Bean, J. C., Poate, J. M., "Evidence for Void Interconnection in Evaporated Amorphous Silicon from Epitaxial Crystallization Measurements," Appl. Phys. Lett. 36, 59 (1980).

209. Foti, G., Bean, J. C., Poate, J. M., and Magee, C. W., "Effect of Structure and Impurities on the Epitaxial Regrowth of Amorphous Silicon," Appl. Phys. Lett. 36, 840 (1980).

210. Hoonhout, D., Kernijk, C. B., and Saris, F. W., "Silicon Epitaxy by Pulsed Laser Annealing of Evaporated Amorphous Films," Phys. Lett. A 66, 145 (1978).

211. Ishiwara, H. and Saitoh, S., "Solid Phase Epitaxy," Oyo Buturi 47, 790 (1978).

212. Lau, S. S., Tseng, W. F., Nicolet, M. A., Mayer, J. W., Eckardt, R. C., and Wagner, R. J., "Epitaxial Growth of Deposited Amorphous Layer by Laser Annealing," Appl. Phys. Lett. 33, 130 (1978).

213. Leamy, H. J., Bean, J. C., Poate, J. M., and Celler, G. K., "Nonequilibrium Incorporation of Impurities during Rapid Solidification," J. Cryst. Growth 48, 379 (1980).

214. Magee, C. W., Bean, J. C., Foti, G., and Poate, J. M., "Observation of Gas Absorption in Evaporated Amorphous Silicon Films Using Secondary Ion Mass Spectroscopy", Thin Sol. Films 81, 1 (1981).

215. Matsui, M., Shiraki, Y., and Maruyama, E., "Low-Temperature Formation of Polycrystalline Silicon Films by Molecular Beam Epitaxy," J. Appl. Phys. 53, 995 (1982).

216. Nakagawa, K., Matsui, M., Katayama, Y., Ishizaka, A., Shiraki, Y., and Maruyama, E., "Molecular Beam Deposited Poly-Si Films for Active Devices," Proc. 2nd Int. Symp. Molecular Beam Epitaxy and Related Clean Surface Techniques (Tokyo, 1982).

217. Nakashima, H., Shiraki, Y., and Miyao, M., "Photoluminescence Study of Laser Annealing in Phosphorus-Implanted and Unimplanted Silicon," J. Appl. Phys. 50, 5966 (1979). 
218. Ohdomari, I. and Onoda, N., "TED Pattern Studies of the Structure of Post-Annealed Amorphous Silicon Layers on Single Crystal Silicon," Phil. Mag. 35, 1373 (1977).

219. Poate, J. M., Bean, J. C., Brown, W. L., Cohen, R. L., Feldman, L. C., Leamy, H. J., Rodgers, J. W, Rousseau, D., Rozgonyi, G. A., Shelnutt, J. A., Sheng, T. T., West, K. W., Williams, J. S., and Celler, G. K., "Liquid and Solid Phase Regrowth of Si by Laser Irradiation and Thermally Assisted Flash Annealing," Radiat. Eff. 48, 167 (1980).

220. Revesz, P., Farkas, G., Mezey, G., and Gyulai, J., "Epitaxial Regrowth of Evaporated Amorphous Silicon by Pulsed Laser Beam, "Appl. Phys. Lett. 33, 431 (1978).

221. Roth, J. A. and Anderson, C. L., "Silicon Epitaxy by Solid-Phase Crystallization of Deposited Amorphous Films," Appl. Phys. Lett. 31, 689 (1977).

222. Saitoh, S., Sugii, T., Ishiwara, H., and Furukawa, S., "Growth Conditions of Deposited Si Films in Solid Phase Epitaxy," Jpn. J. Appl. Phys. 20, L130 (1981).

223. Yonehara, T., Saitoh, T., Kawarada, H., Hirata, T., Kakumu, M., and Ohdomari, I., "Annealing Behavior of Spin Density in UHV Evaporated Amorphous Silicon," Phys. Lett. A 78A, 192 (1980).

See also reference(s) 105,206

\section{REFERENCES BY AUTHORS}

\begin{tabular}{|c|c|}
\hline ABROSIMOVA, L. N. & 106 \\
\hline AESCHLIMANN, $\mathbf{R}$. & 144,145 \\
\hline ALEXSANDROV, L. N. & 62,120 \\
\hline ALLEN, F. A. & $1,64,73$ \\
\hline ANDERSON, C. L. & 221 \\
\hline ARAI, $\mathrm{K}$ & 103 \\
\hline ARBINK, H. C. & 9 \\
\hline ARCHER, J. M. & 24 \\
\hline ARCHER, V. D. & 54,119 \\
\hline ARUSHANOV, A. Y. & 63 \\
\hline ASANO, $\mathrm{T}$. & $154,156,176$ \\
\hline $\mathbf{B A B A}, \mathbf{S}$ & 158,171 \\
\hline BALLAMY, W. C. & 195 \\
\hline BANIGER, U. & 145 \\
\hline BARTH, $\mathrm{H}$. & 197,200 \\
\hline BEAN, J. C. & $\begin{array}{l}2,3,6,44,49,65,66,67,139,159,160,161,162 \\
177,178,194,205,206,207,208,209,213,214,219\end{array}$ \\
\hline BECKER, G. E. & $45,49,65$ \\
\hline BECKERS, L. J. & 138 \\
\hline BELORUSETS, E. D. & 120 \\
\hline BENNETT, R. J. & $68,69,70$ \\
\hline BICKNELL, R. W. & 10 \\
\hline BOOKER, G. R. & $\begin{array}{l}11,12,13,14,15,16,17,18,19,20 \\
21,22,24,28,29,40,41\end{array}$ \\
\hline BOUCHIER, D. & $121,129,130$ \\
\hline BRADLEY, R: R. & $15,27,28,29,41$ \\
\hline BREUER, $\mathbf{K}$. & 136 \\
\hline BROUDY, R. M. & 9 \\
\hline BROWN. W. L. & 219 \\
\hline BUCHANAN, W. L. & 203 \\
\hline
\end{tabular}




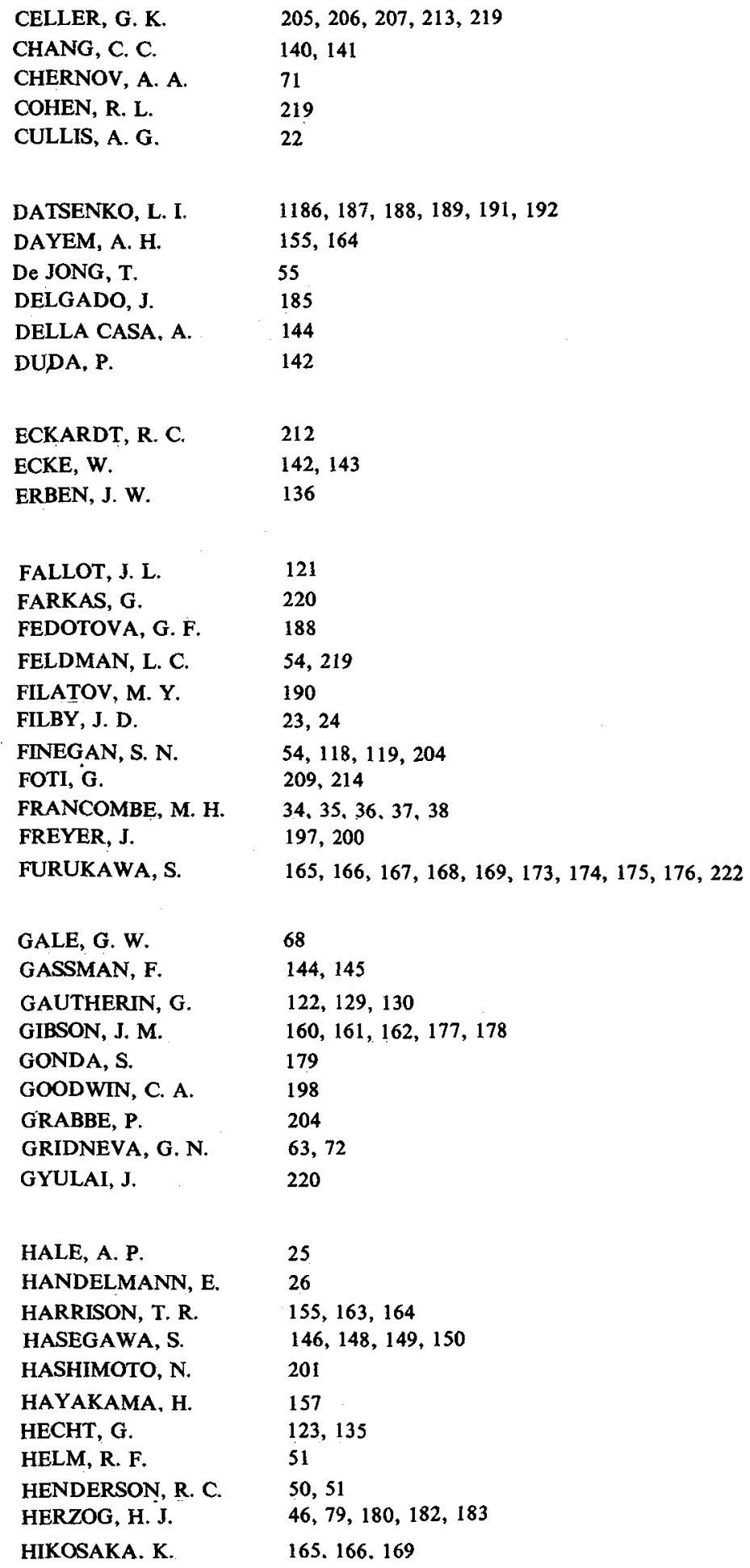




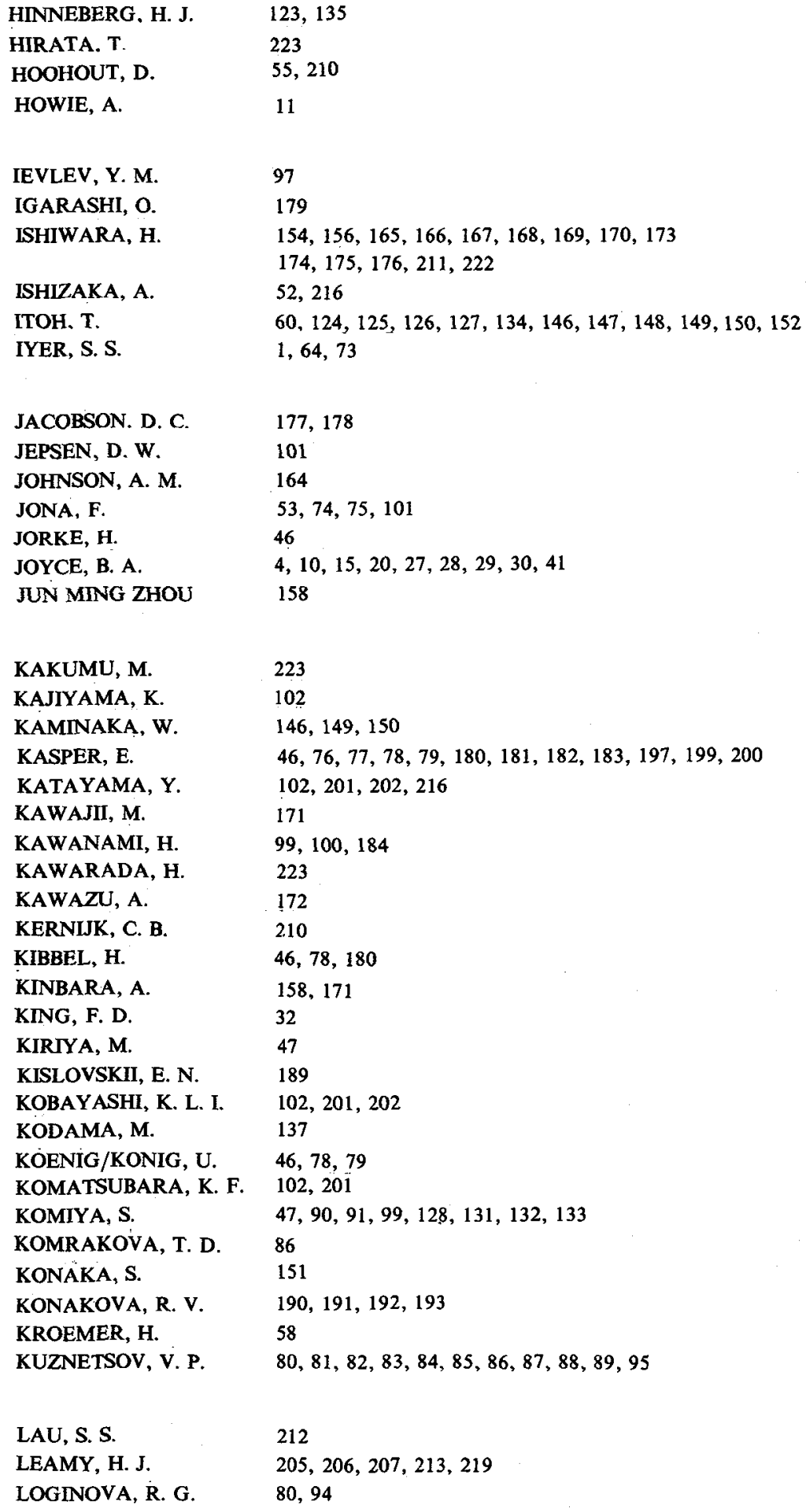




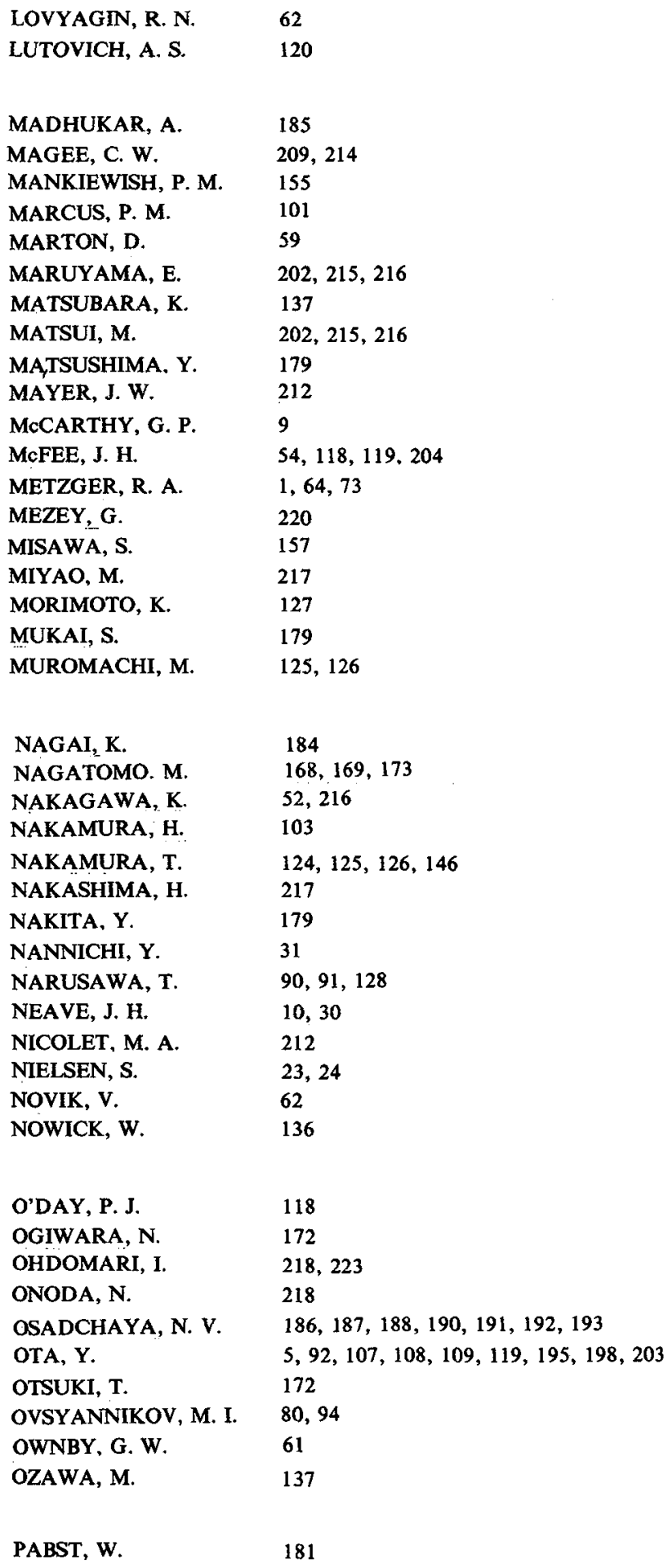

$\begin{array}{ll}\text { PABST, W. } & 181\end{array}$ 


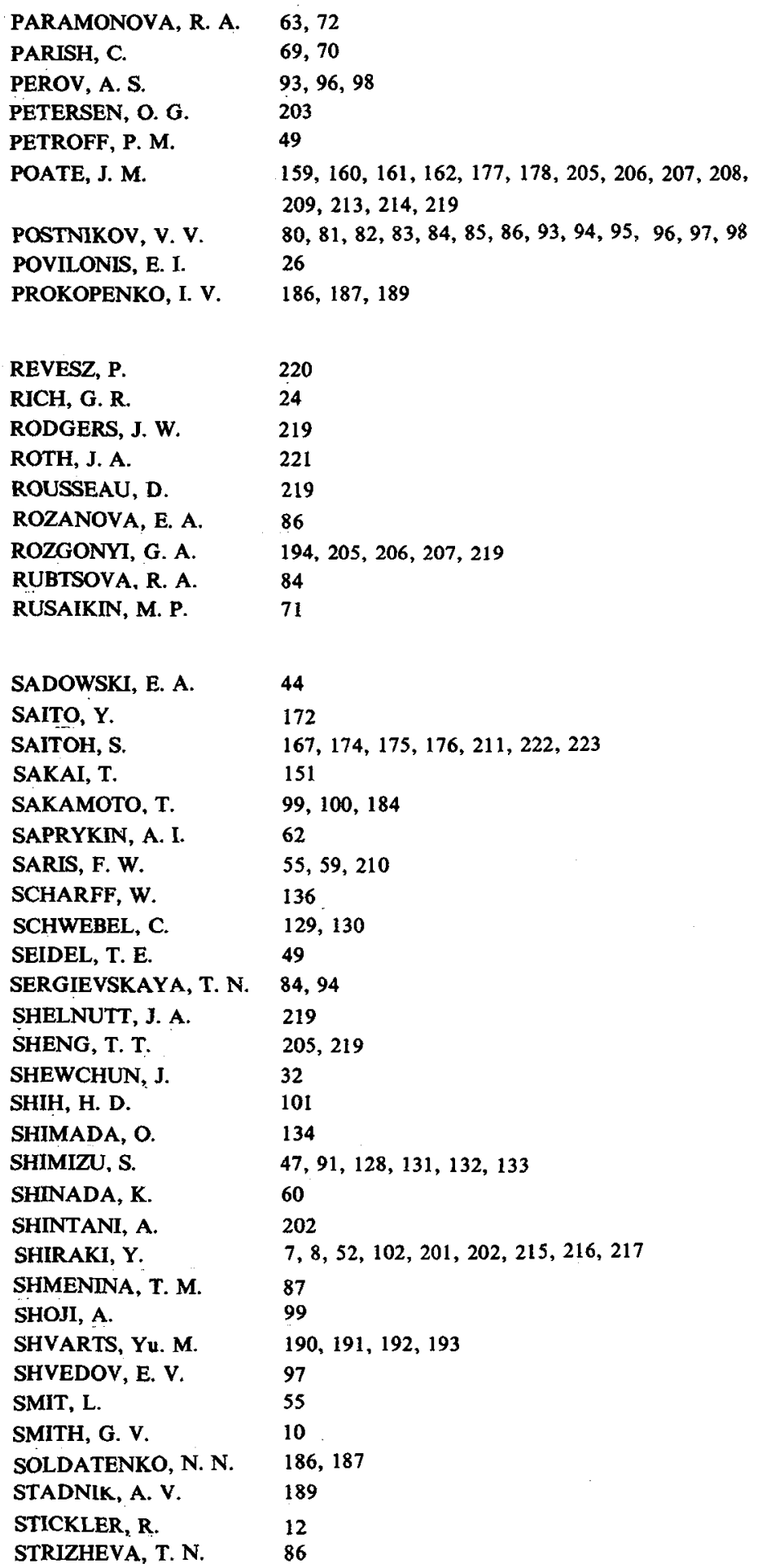


SUGII, T.

SUGIURA, H.

SUGIYAMA, T.

SUZZUKI, E.

SWARTZ, R. G.

TABE, M.

TAKADA, $\mathbf{S}$.

TAKAGI, $T$.

TAKAHASHI, $T$.

TAKAI, $\mathrm{H}$.

TARAI, Y.

THEETEN, J. B.

THOMAS, D. J. D.

THOMAS, R. N.

TIEN, P. K.

TKHORIK, Y. A.

TOLOMASOV, V, A.

TOMANOVA, A. N.

TOMUNAGA, G.

TORCHUN, N. M.

TSENG, W. F.

TUNG, R. T.

UNVALA, B. A.

VALDRE， U.

VAN DER ZIEL, J. P.

VAPAILLE, A.

VASILEVSKAYA, V. N

VOSHCHENKOV, A. M.
222

$48,56,57,110,111,112,113,114,115,116,117$

$125,126,134$

99. 184

$54,118,119,204$

$103,104,151$

157

137

99, 184

152

99

105

33

$34,35,36,37,38$

164

$186,187,188,190,192,193$

$82,87,88,94,106$

88

172

188,193

212

$160,161,162,177,178$

$13,14,16,17,39,40$

19

206, 207

$121,129,130$

$186,187,188,189,190,191,192,193$

118,119

212

127,148

$29,30,41$

123

42

$122,135,136$

219

61

43

205, 206, 207

58

60

59

56,57

60

$\begin{array}{ll}\text { YASUDA, Y. } & 153 \\ \text { YONEHARA, T. } & 223\end{array}$

$\begin{array}{ll}\text { YASUDA, Y. } & 153 \\ \text { YONEHARA, T. } & 223\end{array}$ 
YOSHIDA, $\mathrm{S}$.

YOSHIKAWA, $\mathrm{H}$.

ZALM, P. C.

138

ZEHNER, D. M.

61

ZOTOVA, T. M.

86 